\title{
LEVELS OF ESSENTIAL AND NON-ESSENTIAL METALS IN LINSEED (LINUM USITATISSIMUM) CULTIVATED IN ETHIOPIA
}

\author{
Desta Mekebo and Bhagwan Singh Chandravanshi* \\ Department of Chemistry, Addis Ababa University, P.O. Box 1176, Addis Ababa, Ethiopia
}

(Received February 14, 2014; revised August 11, 2014)

\begin{abstract}
The levels of essential and non-essential metals were determined in linseed (Linum usitatissimum) samples collected in November 2011 from five different sites (Bale, East Gojam, Shoa, South Wello and Tigray) in Ethiopia where its cultivation is common. A $0.5 \mathrm{~g}$ dried powdered linseed was digested with $2 \mathrm{~mL}$ of nitric acid $\left(\mathrm{HNO}_{3}\right), 1 \mathrm{~mL}$ of perchloric acid $\left(\mathrm{HClO}_{4}\right)$ and $1 \mathrm{~mL}$ of hydrogen peroxide $\left(\mathrm{H}_{2} \mathrm{O}_{2}\right)$ at $270{ }^{\circ} \mathrm{C}$ for $2: 30$ hours and the levels of metals determined by flame atomic absorption spectrometer. The accuracy of the optimized procedure was evaluated by analyzing the digest of the spiked samples with standard solution. Recoveries of the spiked samples varied from $91 \%$ to $109 \%$. The levels $\left(\mathrm{mg} \mathrm{kg}^{-1}\right)$ of metals determined were in the ranges $\mathrm{Na}(242-614), \mathrm{K}$ (6,494-6,755), Mg (2,679-3,118), Ca (540-744), Cr (13-30), Mn (17-28), Fe (198-242), Co (23-42), Ni (12-16), $\mathrm{Cu}(25-45), \mathrm{Zn}(29-40)$, and $\mathrm{Pb}(12-32)$. Cd was below method detection limit. $\mathrm{K}$ and $\mathrm{Fe}$ were with the highest concentration from major and trace metals, respectively. Analysis of variance (ANOVA) at 95\% confidence level indicated that there is significant difference in the levels of all metals between the five samples means except $\mathrm{K}$ and $\mathrm{Ni}$. The results indicated that Ethiopian linseed is a good source of essential metals and free from the toxic metal $\mathrm{Cd}$ but not from $\mathrm{Pb}$.
\end{abstract}

KEY WORDS: Linseed, Linum usitatissimum, Essential metals, Non-essential metals, Ethiopia

\section{INTRODUCTION}

Linseed (Linum usitatissimum) is an erect annual, forming a short taproot with fibrous branches which may extend $90-120 \mathrm{~cm}$ in light soils. Linseed stands fourth after mustard, sesame and groundnut in edible oil production of the world [1]. Linseed has been a traditional crop in Ethiopia and it is the second most important oil crop in production after niger (Guizotia abyssinica) in the higher altitudes [2]. Ethiopia is the $5^{\text {th }}$ major producer of linseed in the world after Canada, China, United States and India [3].

The principal linseed growing regions in Ethiopia are located at altitudes between 1800 and 2800 meter above sea level (masl), although it occasionally grows at altitudes as low as 1680 masl or as high as 3430 masl [4]. Arsi, Bale, Chercher Mountains, Eastern Welega, Eastern Gojam, Tigray, Southeast Wello, and Shoa are the major areas of production and South Gondar, Kefa, Gemogofa and Illubabor are small-scale production areas in Ethiopia. Linseed is a major oilseed and rotation crop for barley in higher elevations of Arsi, Bale, Gojam, Gonder, Wello, Shoa and Welega. High yields of wheat, barley and tef can be obtained following linseed [5]. In Ethiopia, in terms of area and production, linseed occupies the second position among the oilseed crops next to niger. The area under this crop is about 177,000 hectares with an average yield of $970 \mathrm{~kg} \mathrm{ha}^{-1}$ [6]. The average area of cultivation of linseed in Ethiopia by small holders was 186,000 hectares with $1.7 \%$ of the total crop production during the period 2003/04-2008/09 $[6]$.

Linseed is a multi-purpose crop. Its' seeds containing about $36-40 \%$ of oil, have long been used in human and animal diets and in industry as a source of oil and as a basic component or additive of various paints or polymers. Recently, there has been a growing interest in the probiotic properties of flax and in its beneficial effects on coronary heart disease, some kinds of cancer and neurological and hormonal disorders [7-9]. The beneficial effects are mostly due to flax lipids. Flax oil is the richest plant source of linoleic (omega-6) and linolenic (omega-3)

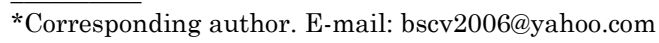


polyunsaturated fatty acids, which are essential for humans since they cannot be synthesized in the organism and must be ingested in food [10].

Scientific research over the past decade all over the world is indicating health benefits of omega-3 type oils, lignin and other soluble fiber present in the flax seed/linseed. Some of the medicinal uses of linseed oil are: flax seed oil mixed with an equal quantity of limewater, known as a rectal oil, is an excellent applicant for burns and scolds, rectal injection of $60 \mathrm{~mL}$ of oil, given at night and morning has been recommended for piles, freshly extracted oil is used as a laxative in doses of $30 \mathrm{~mL}$, linseed oil is a vehicle for irritant drugs, linseed tea is prepared by boiling one part of linseed with 20 parts of water until grains become soft (the tea is used as a demulcent in cough especially those forms due to irritation of pharynx and upper part of respiratory passage. It is also used as a demulcent drink in intestinal or urinary catarrhs), for the preparation of cough syrup mucilage of linseed ( 1 in 8 parts of water) is used, crushed linseed is used in the form of poultice to apply warmth and moisture locally for the relief of superficial or deep rooted inflammation (it is prepared by boiling $28 \mathrm{~g}$ linseed with $72 \mathrm{~mL}$ of water. The poultice may be sprinkled with boric acid previous to application. The poultice mass is enclosed in muslin, the surface of poultice may be smeared with oil to keep it adhering to skin), linseed/flax seed and its oil have anti-inflammatory action the treatment of arthritis, feeding linseed and its oil may be indicated in hyperlipidemia to decrease platelet aggregation and also to reduce and control atherosclerosis, thrombosis and myocardial infraction by reducing cholesterol and low density lipids. It also lowers blood pressure [11].

In some European countries (Bulgaria, Germany, Hungary and Czech Republic) there were some investigations indicating the metal contents besides oil, protein, fatty acid and fiber contents [12]. The research in these countries showed that linseed has recently gained popularity as a health food product. It has high levels of fatty acids and minerals, giving it characteristics beneficial for functional foods. The levels of ten minerals $(\mathrm{K}, \mathrm{Na}, \mathrm{Mg}, \mathrm{Ca}, \mathrm{Mn}, \mathrm{Fe}, \mathrm{P}, \mathrm{Cu}, \mathrm{Zn}$ and B) were also determined and showed significant variability between lines [12]. In another research carried out in Pakistan [13] at differently processed linseed flours, roasting has not significantly affected the mineral contents of the flaxseed except $\mathrm{Fe}, \mathrm{Cu}$ and $\mathrm{Zn}$. Partial defattening resulted in a significant increase in the mineral content of the flax seed flours. Based on the recommended daily intakes and on the values obtained in that study, it is clear that flaxseed flour could be important in contributing to the overall daily dietary intake of essential elements especially the micronutrients whose deficiency is widespread in Pakistan [13].

In a study carried out in Italy [14], the contents of minerals in 35 different medicinal plants including linseed were analyzed. According to this study the mineral contents differs from one another depending on soil composition and the climate in which the plant grows. In another study conducted on some medicinal plants being used as food condiments including linseed in South Asian region, their composition by different methods and metals content by FAAS have been determined [15].

In recent years, there has been a growing interest in monitoring trace elements and heavy metal contents in some spices and herbs widely cultivated and consumed in Turkey including $\mathrm{Mn}, \mathrm{Fe}, \mathrm{Cu}, \mathrm{Zn}$ and $\mathrm{Cd}$, by ICP-AES. In that study the highest levels of metals determined in linseed were $\mathrm{Zn}\left(28 \mathrm{mg} \mathrm{kg}^{-1}\right)$ and $\mathrm{Cd}\left(0.13 \mathrm{mg} \mathrm{kg}^{-1}\right)$ and the concentration of the other metals was intermediate. The results of that study revealed that trace metal contents of some selected spices plants commonly cultivated in Turkey were within the low range [16].

Very recently, there has been a growing interest in monitoring trace elements and heavy metal contents in some spices and herbs widely cultivated and consumed in Ethiopia. These studies include levels of selected metals in the leaves of different species of thyme (T. schimperi and T. vulgaris) [17], metallic nutrients in enset (Ensete ventricosum) corm [18], levels of major and trace metals in onion (Allium cepa L.) [19], levels of metals in vegetables [20], levels of essential and non-essential metals in Rhamnus prinoides (Gesho) [21], mineral composition of Sorghum Landrace Accessions from Ethiopia [22], mineral contents of fruits of cactus pear 
(Opuntia ficus indica) [23] and levels of major, minor and toxic metals in tubers and flour of Dioscorea abyssinica [24]. Mineral contents of seed and seed oils of Capparis species growing wild in Turkey have been reported during this year [25].

However, there is no research conducted in Ethiopia that is relevant to essential and nonessential metals or related to minerals content in linseed, even though Ethiopia is the $5^{\text {th }}$ major producer of linseed. Therefore, the present study aimed to: (i) determine the concentrations of major $(\mathrm{Na}, \mathrm{K}, \mathrm{Mg}, \mathrm{Ca})$, trace $(\mathrm{Cr}, \mathrm{Mn}, \mathrm{Fe}, \mathrm{Co}, \mathrm{Ni}, \mathrm{Cu}, \mathrm{Zn})$, and toxic $(\mathrm{Cd}, \mathrm{Pb})$ metals in linseed; (ii) compare the levels of metals in linseed samples from the different regions of Ethiopia; and (iii) compare the levels of metals in linseed from Ethiopia with literature data.

\section{EXPERIMENTAL}

\section{Equipments}

Electronic blending device (Moulinex, France) was used for grinding and homogenizing the sample. A $100 \mathrm{~mL}$ round bottom flasks fitted with reflux condensers were used in Kjeldahl (UK) apparatus hot plate to digest the dried and powdered linseed samples. Borosilicate volumetric flasks $(50$ and $100 \mathrm{~mL}$ ) were used during dilution and preservation of samples and preparation of metals standard solutions. Volumetric pipettes (Pyrex, USA) with 1, 2, 5 and 10 $\mathrm{mL}$ capacity were used for measuring oxidizing reagents used for optimization of digestion procedure and preparation of samples as well as intermediate standards. Flame atomic absorption spectrophotometers (Buck Scientific Model 210 VGP AAS, East Norwalk, USA) equipped with deuterium arc back ground connectors and hollow cathode lamps with airacetylene flame was used for the analysis of the analyte metals $(\mathrm{K}, \mathrm{Na}, \mathrm{Mg}, \mathrm{Ca}, \mathrm{Cr}, \mathrm{Mn}, \mathrm{Fe}, \mathrm{Co}$, $\mathrm{Ni}, \mathrm{Cu}, \mathrm{Zn}, \mathrm{Cd}$ and $\mathrm{Pb}$ ) in the samples.

\section{Reagents and chemicals}

$\mathrm{HNO}_{3}(69-72 \%), \mathrm{HClO}_{4}(60 \%)\left(\mathrm{BDH}\right.$ Laboratory Supplies AnalaR ${ }^{\circledR}$, Poole England) and extra pure $\mathrm{H}_{2} \mathrm{O}_{2}(30 \%)$ (Scharlau Chemie S.A., European Union, Spain) were used for digestion of linseed samples. Lanthanum(III) nitrate hexahydrate $\left(\mathrm{La}\left(\mathrm{NO}_{3}\right)_{3} \cdot 6 \mathrm{H}_{2} \mathrm{O}\right)(98 \%)$ (BDH Chemicals Ltd, Poole England) was used to minimize the precipitation of $\mathrm{Ca}$ and $\mathrm{Mg}$ ions in the form of phosphates and sulfates. Stock standard solutions containing $1000 \mathrm{mg} \mathrm{L}^{-1}$, in $2 \% \mathrm{HNO}_{3}$, of the metals $\mathrm{K}, \mathrm{Na}, \mathrm{Mg}, \mathrm{Ca}, \mathrm{Cr}, \mathrm{Mn}, \mathrm{Fe}, \mathrm{Co}, \mathrm{Ni}, \mathrm{Cu}, \mathrm{Zn}, \mathrm{Cd}$ and $\mathrm{Pb}$ (BDH Chemicals Ltd Spectrosol $^{\circledR}$, Poole England) were used for preparation of calibration standards and in the spiking experiments. Deionized water was used for dilution of sample and intermediate metal standard solutions prior to analysis and rinsing glassware.

\section{Sample site description, collection and transportation}

Efforts were made to ensure representativeness in Ethiopian context by collecting samples from the most widely cultivated areas in Ethiopia in November 2011. The geographical locations of these sampling sites lie between the latitude $7^{\circ} 1^{\prime}-14^{\circ} 15^{\prime} \mathrm{N}$, longitude $37^{\circ} 43^{\prime}-40^{\circ} 40^{\prime} \mathrm{E}, 1750-2840$ masl and within the distance $809 \mathrm{~km}$ from Addis Ababa (capital city of Ethiopia) in all directions.

Recently cultivated linseed samples were collected from five major cultivation sites: Bale (Ginir, Goba and Robe, Oromia Region), East Gojam (Bichena, Debre Markos and Mota, Amhara Region), Shoa (Debre Birhan, Fiche and Hossaina, Amhara Region, Oromia Region and SNNPRS, respectively), South Wello (Dessie, Kombolcha and Wegeltena, Amhara Region) and Tigray (Adwa, Mekele and Wukro, Tigray Region). From a particular main site, three subsites were selected for the purpose of random sampling. About $500 \mathrm{~g}$ of the sample was taken 
from each sub-sites and then mixed in to a single polyethylene plastic bags to get $1.5 \mathrm{~kg}$ of one bulk sample. The collected samples were packed into polyethylene plastic bags, labeled and transported to laboratory for further treatment.

\section{Sample preparation}

The linseed samples were washed with a running tap water to remove adsorbed soil particulates and then rinsed with deionized water. The samples were exposed to sun light for several days to reduce the moisture content and get constant weight so as to express the results in terms of dry mass basis. The dried linseed was ground using electronic blender and sieved (using $0.5 \mathrm{~mm}$ sieve) to prepare fine powder of linseed for digestion. Then the fine powder of linseed samples was kept in properly washed, dried and cleaned polyethylene plastic bags until appropriate amounts of the samples were taken for digestion.

\section{Optimization of digestion procedure}

Wet acid digestion is one of the methods that are involved to get free metal ions in dissolved form from complex organic matrix based on changing different digestion parameters like volume ratio of reagents added, digestion temperature and duration of time. One of the wet acid digestions can be carried out by Kjeldahl apparatus in which organic components are assumed to decompose in the form of different gaseous forms and other metallic elements are left in the solution except those easily volatile metals like Hg. Moreover, it is assumed that digestion is assumed to be complete if the solution is clear and colorless. Based on this fact the optimized condition for sample preparation in this study was $\left(2 \mathrm{~mL} \mathrm{HNO}_{3}: 1 \mathrm{~mL} \mathrm{H}_{2} \mathrm{O}_{2}: 1 \mathrm{~mL} \mathrm{HClO}_{4}\right)$ volume ratio of reagents, $270{ }^{\circ} \mathrm{C}$ digestion temperature and $2: 30$ hour digestion time.

\section{Digestion of samples}

Applying the optimized conditions mentioned above, $0.5 \mathrm{~g}$ of powdered linseed samples were transferred into a $100 \mathrm{~mL}$ round bottom flask. Then $4 \mathrm{~mL}$ of a mixture of $\mathrm{HNO}_{3}(69-72 \%)$, $\mathrm{HClO}_{4}(60 \%)$ and $\mathrm{H}_{2} \mathrm{O}_{2}(30 \%)$ with a volume ratio of $2: 1: 1(\mathrm{v} / \mathrm{v})$ was added and the mixture digested on a Kjeldahl digestion apparatus fitted with a reflux condenser by setting the temperature first to $30^{\circ} \mathrm{C}$ for $10 \mathrm{~min}$, second to $60^{\circ} \mathrm{C}$ for $10 \mathrm{~min}$, third to $120^{\circ} \mathrm{C}$ for $10 \mathrm{~min}$ and then raising to $270{ }^{\circ} \mathrm{C}$ for the remaining 2 hours. The digest was allowed to cool to room temperature for $30 \mathrm{~min}$ without dismantling the condenser and for $10 \mathrm{~min}$ after removing the condenser. To the cooled solution $15 \mathrm{~mL}$ of deionized water was added to dissolve the precipitate formed on cooling and to minimize dissolution of filter paper by the digest residue while filtering with Whatman, (110 mm and $125 \mathrm{~mm}$, diameter) filter paper into $50 \mathrm{~mL}$ volumetric flask. The round bottom flask was rinsed subsequently with $5 \mathrm{~mL}$ deionized water until the total volume reached around $45 \mathrm{~mL}$. To this final solution, about $0.67 \mathrm{~g}$ of $\mathrm{La}\left(\mathrm{NO}_{3}\right)_{3} \cdot 6 \mathrm{H}_{2} \mathrm{O}$ was added and the solution was filled to the mark $(50 \mathrm{~mL})$ with deionized water. This addition of $\mathrm{La}\left(\mathrm{NO}_{3}\right)_{3} \cdot 6 \mathrm{H}_{2} \mathrm{O}$ prevents the precipitation of $\mathrm{Ca}^{2+}$ and $\mathrm{Mg}^{2+}$ with the $\mathrm{SO}_{4}{ }^{2-}$ and $\mathrm{PO}_{4}{ }^{3-}$ (in which the anions may be formed from incomplete removal of the elements $\mathrm{P}$ and $\mathrm{S}$ from organic matter). As such the process of FAAS is element specific and the above addition makes $\mathrm{Ca}^{2+}$ and $\mathrm{Mg}^{2+}$ to be free for atomization and the $\mathrm{SO}_{4}^{-2}$ and $\mathrm{PO}_{4}^{-3}$ probably present in the solution is precipitated.

The digestion was carried out in triplicate for each bulk sample. Digestion of a reagent blank was also performed in parallel with the linseed samples keeping all digestion parameters the same. The digested samples were kept in the refrigerator, until the level of all the metals in the sample solutions were determined by FAAS. 


\section{Determination of metals in linseed samples}

Calibration metal standard solutions were prepared for each of the metals from an intermediate standard solution containing $10 \mathrm{mg} \mathrm{L}^{-1}$ which was prepared from the atomic absorption spectroscopy standard stock solutions that contained $1000 \mathrm{mg} \mathrm{L}^{-1}$. These secondary standards were diluted with deionized water to obtain four working standards for each metal of interest. Then $\mathrm{K}, \mathrm{Na}, \mathrm{Mg}, \mathrm{Ca}, \mathrm{Cr}, \mathrm{Mn}, \mathrm{Fe}, \mathrm{Co}, \mathrm{Ni}, \mathrm{Cu}, \mathrm{Zn}, \mathrm{Cd}$ and $\mathrm{Pb}$ were analyzed with FAAS equipped with deuterium arc background corrector and standard air-acetylene flame system using external calibration curve after the parameters (burner and lamp alignment, slit width and wavelength adjustment) were optimized for maximum signal intensity of the instrument. Three replicate determinations were carried out on each sample. Hallow cathode lamp for each metal operated at the manufacturer's recommended conditions were used at its respective primary source line. The acetylene and air flow rates were managed to ensure suitable flame conditions. All thirteen metals were determined by absorption/concentration mode and the instrument readout was recorded for each solution manually. The same analytical procedure was employed for the determination of elements in the digested blank solutions.

\section{Instrument calibration}

The FAAS was calibrated using four series of working standards. The working standard solutions of each metal were prepared freshly by diluting the intermediate standard solutions (10 $\mathrm{mg} \mathrm{L}^{-1}$ ). The calibrated instrumental operating conditions including its determined method detection limit are shown in Table 1. The correlation coefficient in Table 1 for each metals shows that the change in absorbance with concentration is in good correlation.

Table 1. The wavelength, method detection limit, correlation coefficient, and calibration curve equation for determination of metals using FAAS.

\begin{tabular}{|c|c|c|c|c|}
\hline Metal & $\begin{array}{c}\text { Wavelength } \\
(\mathrm{nm})\end{array}$ & $\begin{array}{c}\text { Method detection } \\
\text { limit }\left(\mathrm{mg} \mathrm{g}^{-1} \text { dry }\right. \\
\text { weight })\end{array}$ & $\begin{array}{c}\text { Correlation } \\
\text { coefficient }\end{array}$ & Calibration curve equation \\
\hline $\mathrm{K}$ & 766.5 & 0.007 & 0.9999 & $\mathrm{Y}=0.00618 \mathrm{X}-5.32 \times 10^{-6}$ \\
\hline $\mathrm{Na}$ & 589.0 & 0.004 & 0.9999 & $\mathrm{Y}=0.0729 \mathrm{X}+1.35 \times 10^{-3}$ \\
\hline $\mathrm{Mg}$ & 284.2 & 0.001 & 0.9999 & $\mathrm{Y}=0.186 \mathrm{X}+1.68 \times 10^{-3}$ \\
\hline $\mathrm{Ca}$ & 422.7 & 0.001 & 0.9999 & $\mathrm{Y}=0.00266 \mathrm{X}-7.04 \times 10^{-5}$ \\
\hline $\mathrm{Cr}$ & 357.9 & 0.002 & 0.9998 & $\mathrm{Y}=0.0101 \mathrm{X}+4.18 \times 10^{-4}$ \\
\hline $\mathrm{Mn}$ & 279.5 & 0.001 & 0.9992 & $\mathrm{Y}=0.0238 \mathrm{X}-2.97 \times 10^{-4}$ \\
\hline $\mathrm{Fe}$ & 248.3 & 0.003 & 0.9999 & $\mathrm{Y}=0.00412 \mathrm{X}+7.15 \times 10^{-5}$ \\
\hline $\mathrm{Co}$ & 240.7 & 0.006 & 0.9999 & $\mathrm{Y}=0.00341 \mathrm{X}+6.35 \times 10^{-5}$ \\
\hline $\mathrm{Ni}$ & 232.0 & 0.003 & 0.9997 & $\mathrm{Y}=0.00699 \mathrm{X}-1.27 \times 10^{-5}$ \\
\hline $\mathrm{Cu}$ & 324.7 & 0.003 & 0.9999 & $\mathrm{Y}=0.0113 \mathrm{X}-6.86 \times 10^{-5}$ \\
\hline $\mathrm{Zn}$ & 213.9 & 0.001 & 0.9999 & $\mathrm{Y}=0.116 \mathrm{X}-1.70 \times 10^{-5}$ \\
\hline $\mathrm{Cd}$ & 213.9 & 0.001 & 0.9999 & $\mathrm{Y}=0.0671 \mathrm{X}+6.27 \times 10^{-4}$ \\
\hline $\mathrm{Pb}$ & 283.2 & 0.005 & 0.9999 & $\mathrm{Y}=0.0671 \mathrm{X}+6.27 \times 10^{-4}$ \\
\hline
\end{tabular}

\section{Method detection limits (MDL)}

The MDL is typically determined to be in the region where the signal-to-noise ratio is greater than 3 but not necessarily quantified as an exact value. It can be calculated by multiplying the pooled standard deviation of the reagent blank $\left(S_{\text {blank }}\right)$ by three $\left(M D L=3 \times S_{\text {blank }}, n=18\right.$ ). Method detection limits of the metals of interest are given in Table 1. The smaller values for 
MDL indicate that the presence of trace amounts of metals of interest in the sample can be detected by the method.

\section{Method validation}

The validity of the optimized procedure was assessed by spiking experiments. For this purpose standard solution of $1000 \mathrm{mg} \mathrm{L}^{-1}$ (from BDH Chemicals Ltd Spectrosol ${ }^{\circledR}$, Poole England) was used and intermediate standards of $100 \mathrm{mg} \mathrm{L}^{-1}$ and $10 \mathrm{mg} \mathrm{L}^{-1}$ were prepared. Thus, spiking was done in three triplicate groups. In the first group $330 \mu \mathrm{L}$ of $1000 \mathrm{mg} \mathrm{L}^{-1}$ of $\mathrm{K}$ was spiked in a flask containing $0.5 \mathrm{~g}$ sample. In the second group $205 \mu \mathrm{L}$ of $1000 \mathrm{mg} \mathrm{L}^{-1}, 24 \mu \mathrm{L}$ of $1000 \mathrm{mg}$ $\mathrm{L}^{-1}, 64 \mu \mathrm{L}$ of $1000 \mathrm{mg} \mathrm{L}^{-1}, 45 \mu \mathrm{L}$ of $1000 \mathrm{mg} \mathrm{L}^{-1}$ and $65 \mu \mathrm{L}$ of $100 \mathrm{mg} \mathrm{L}^{-1}$ of $\mathrm{Na}, \mathrm{Mg}, \mathrm{Ca}, \mathrm{Fe}$ and $\mathrm{Co}$, respectively, were spiked in a flask containing $0.5 \mathrm{~g}$ sample. In the third group $40 \mu \mathrm{L}$ of $100 \mathrm{mg} \mathrm{L}^{-1}, 50 \mu \mathrm{L}$ of $100 \mathrm{mg} \mathrm{L}^{-1}, 35 \mu \mathrm{L}$ of $100 \mathrm{mg} \mathrm{L}^{-1}, 80 \mu \mathrm{L}$ of $100 \mathrm{mg} \mathrm{L}^{-1}, 75 \mu \mathrm{L}$ of $100 \mathrm{mg}$ $\mathrm{L}^{-1}, 50 \mu \mathrm{L}$ of $10 \mathrm{mg} \mathrm{L}^{-1}$ and $70 \mu \mathrm{L}$ of $100 \mathrm{mg} \mathrm{L}^{-1}$ of $\mathrm{Cr}, \mathrm{Mn}, \mathrm{Ni}, \mathrm{Cu}, \mathrm{Zn}, \mathrm{Cd}$ and Pd, respectively, were in the flask containing the same amount of sample as the previous.

The spiked and non-spiked samples were digested and analyzed in similar condition using optimized procedure before for sample analysis. The results of recovery analysis are shown in Table 2 and the percentage recoveries lies within the range $91-114 \%$. The percentage recovery for linseed samples are between 90 to $110 \%$ (100 \pm 10$)$, which are within the acceptable range for all metals except $\mathrm{Pb}$, for which a recovery of $114 \%$ was obtained. The higher recovery for $\mathrm{Pb}(114 \%)$ may be attributed to the contamination of the sample with different $\mathrm{Pb}$ potential sources such as $\mathrm{Pb}$ acid battery while transportation and contamination while storing by local farmers and sample preparation before analysis.

Table 2. Recovery test for the optimized procedure of linseed sample.

\begin{tabular}{|c|c|c|c|c|c|}
\hline Metal & $\begin{array}{c}\text { Concentration of } \\
\text { sample }\left(\mathrm{mg} \mathrm{kg}^{-1}\right)\end{array}$ & $\begin{array}{c}\text { Amount spiked } \\
\left(\mathrm{mg} \mathrm{kg}^{-1}\right)\end{array}$ & $\begin{array}{c}\text { Concentration of spiked } \\
\text { sample }\left(\mathrm{mg} \mathrm{kg}^{-1}\right)\end{array}$ & $\begin{array}{c}\text { Amount recovered } \\
\left(\mathrm{mg} \mathrm{kg}^{-1}\right)\end{array}$ & $\begin{array}{c}\text { Percent recovery } \\
(\% \mathrm{R})\end{array}$ \\
\hline $\mathrm{K}$ & $10,500 \pm 43$ & 660 & $11,105 \pm 39$ & $605 \pm 58$ & $92 \pm 9$ \\
\hline $\mathrm{Na}$ & $220 \pm 0.5$ & 48 & $272 \pm 0.9$ & $52 \pm 1.0$ & $108 \pm 2$ \\
\hline $\mathrm{Mg}$ & $2,744 \pm 17$ & 411 & $3,133 \pm 25$ & $389 \pm 30$ & $95 \pm 7$ \\
\hline $\mathrm{Ca}$ & $689 \pm 6$ & 127 & $805 \pm 10$ & $116 \pm 11.7$ & $91 \pm 9$ \\
\hline $\mathrm{Cr}$ & $33 \pm 0.4$ & 8 & $41.7 \pm 0.6$ & $8.7 \pm 0.72$ & $109 \pm 9$ \\
\hline $\mathrm{Mn}$ & $26.4 \pm 0.5$ & 10 & $35.9 \pm 0.6$ & $9.5 \pm 0.78$ & $95 \pm 8$ \\
\hline $\mathrm{Fe}$ & $138 \pm 1.1$ & 89 & $223 \pm 1.5$ & $85 \pm 1.86$ & $96 \pm 2$ \\
\hline $\mathrm{Co}$ & $22.0 \pm 0.9$ & 13 & $34.7 \pm 1$ & $12.7 \pm 1.3$ & $98 \pm 10$ \\
\hline $\mathrm{Ni}$ & $14 \pm 0.5$ & 7 & $21.6 \pm 0.5$ & $7.6 \pm 0.71$ & $109 \pm 10$ \\
\hline $\mathrm{Cu}$ & $25 \pm 0.8$ & 16 & $42 \pm 0.7$ & $17 \pm 1.06$ & $106 \pm 7$ \\
\hline $\mathrm{Zn}$ & $35.0 \pm 0.7$ & 15 & $48.9 \pm 0.1$ & $13.9 \pm 0.71$ & $93 \pm 5$ \\
\hline $\mathrm{Cd}$ & $\mathrm{ND}$ & 1 & $1.92 \pm 0.05$ & $0.92 \pm 0.05$ & $92 \pm 5$ \\
\hline $\mathrm{Pb}$ & $30 \pm 0.9$ & 14 & $46 \pm 1$ & $16 \pm 1.3$ & $114 \pm 9$ \\
\hline
\end{tabular}

$\mathrm{ND}=$ not detected

\section{Data analysis}

Origin 6.0 software was used for the preparation of calibration curves and the data analysis. One way ANOVA was used for the experimental design and to compare the mean values the metals between different sampling sites. Pearson correlation coefficient was used to determine the degree of positive or negative correlation between the metals. 


\section{RESULTS AND DISCUSSIONS}

\section{Levels of metals in linseed samples}

The determination of metals level was carried out by FAAS and the accuracy and precision of the results was determined by different statistical methods as described in experimental section. Percent relative standard deviation (\% RSD) all the results were in good range, i.e. all the values determined were in the range of mean value $(\bar{X}) \pm 10 \%$. Mean values were determined from triplicate analysis of each sample and triplicate samples were used for each sample site. As such the mean values determined were triplicate of triplicate analysis for each metal and the results were in terms of mean values $(\bar{X}) \pm \mathrm{SD}$ (where $\mathrm{n}=9$, for all the metals in this study). Among the analyzed metals the value for $\mathrm{Cd}$ was not detected because it was below method detection limit. Results are listed in terms of mean value and standard deviation (SD) of $\mathrm{mg} \mathrm{kg}^{-1}$ dry weight bases and percent relative standard deviation in Table 3 .

Table 3. Mean concentration $\left(\overline{\boldsymbol{x}} \pm \mathrm{SD}, \mathrm{n}=9, \mathrm{mg} \mathrm{kg}^{-1}\right.$ dry weight) of major, trace and toxic metals in each sample sites analyzed by FAAS.

\begin{tabular}{|c|c|c|c|c|c|}
\hline \multirow{2}{*}{ Metal } & \multicolumn{5}{|c|}{ Sampling site } \\
\cline { 2 - 6 } & Bale & East Gojam & Shoa & South Wello & Tigray \\
\cline { 2 - 6 } & $\bar{N} \pm \mathrm{SD}$ & $\bar{N} \pm$ SD & $\bar{N} \pm$ SD & $\bar{N} \pm$ SD & $\bar{N} \pm$ SD \\
\hline $\mathrm{K}$ & $6522 \pm 71$ & $6494 \pm 68$ & $6755 \pm 78$ & $6644 \pm 47$ & $6539 \pm 61$ \\
\hline $\mathrm{Na}$ & $242 \pm 21$ & $503 \pm 25$ & $314 \pm 21$ & $614 \pm 23$ & $525 \pm 28$ \\
\hline $\mathrm{Mg}$ & $2740 \pm 28$ & $3029 \pm 28$ & $3013 \pm 23$ & $3118 \pm 25$ & $2679 \pm 23$ \\
\hline $\mathrm{Ca}$ & $635 \pm 18$ & $622 \pm 6$ & $624 \pm 20$ & $744 \pm 8$ & $540 \pm 9$ \\
\hline $\mathrm{Cr}$ & $16 \pm 0.4$ & $13 \pm 0.9$ & $30 \pm 1$ & $27 \pm 0.6$ & $33 \pm 1.8$ \\
\hline $\mathrm{Mn}$ & $23 \pm 0.6$ & $28 \pm 1$ & $22 \pm 1$ & $22 \pm 1$ & $17 \pm 0.5$ \\
\hline $\mathrm{Fe}$ & $198 \pm 2$ & $232 \pm 0.8$ & $242 \pm 9$ & $201 \pm 0.7$ & $216 \pm 7$ \\
\hline $\mathrm{Co}$ & $28 \pm 0.5$ & $42 \pm 0.4$ & $30 \pm 1$ & $37 \pm 3.6$ & $23 \pm 2$ \\
\hline $\mathrm{Ni}$ & $14 \pm 1.3$ & $15 \pm 0.7$ & $15 \pm 1.2$ & $16 \pm 1.4$ & $12 \pm 1.0$ \\
\hline $\mathrm{Cu}$ & $35 \pm 0.9$ & $25 \pm 0.8$ & $37 \pm 0.9$ & $45 \pm 3.8$ & $41 \pm 2$ \\
\hline $\mathrm{Zn}$ & $33 \pm 0.1$ & $35 \pm 0.6$ & $29 \pm 0.8$ & $34 \pm 0.3$ & $40 \pm 1$ \\
\hline $\mathrm{Cd}$ & $\mathrm{ND}$ & $\mathrm{ND}$ & $\mathrm{ND}$ & $\mathrm{ND}$ & $\mathrm{ND}$ \\
\hline $\mathrm{Pb}$ & $32 \pm 2.5$ & $12 \pm 1$ & $17 \pm 1.5$ & $28 \pm 1$ & $22 \pm 2$ \\
\hline
\end{tabular}

$\mathrm{ND}=$ Concentration of the metal was below the method detection limit $\left(<0.001 \mathrm{mg} \mathrm{g}^{-1}\right)$.

\section{Distribution patterns of metals in the samples}

Metals uptake by plants may occur through different and complex biochemical processes. This uptake varies based on the ability of the plants to absorb metals from the soil, the availability of the mineral elements in soluble and absorbable forms, the abundance of specific metals at the specified site, and the contamination level of the soil with heavy metals. The variation of metals levels in soil arises because of increasing industrialization and associated pollution of the biosphere, use of different types of fertilizers, pesticide treatment, and others are the main contributors. The use of sewage sludge, pesticides, irrigation of waters and fertilizers on agricultural land has made some of that land of questionable quality for production of food for humans and animals. The distribution and accumulation of metals in linseed are the reflection of the mineral composition of the soil and environment in which linseed plant grows. Therefore, the actual metal content of linseed vary considerably according to geographic origin, the use of fertilizers with different chemical compositions and other characterizing features such as water for irrigation. 


\section{Concentration of macro-essential (major) metals in linseed}

Plants accumulate metals from the soil and environment in different parts. The amount of metals accumulated in the plant varies in different edible parts. But this study focuses the level of metals in seed of linseed because the common edible part of it is its seed for human beings. There is a variation in the metal concentration of macro-essential metals among the sample sites. As the results in Table 3 show that highest concentration of $K$ was within the range $(6,494$ $6,755 \mathrm{mg} \mathrm{kg}^{-1}$ dry weight) in all sites followed by $\mathrm{Mg}$ within the range $\left(2,679-3,118 \mathrm{mg} \mathrm{kg}^{-1}\right.$ dry weight) which is the second with highest concentration next to $\mathrm{K}$. Ca was the third in its concentration level followed by $\mathrm{Na}$ which is the forth one among the macro-essential minerals in most sample sites. In short the concentration profile of macro-essential metals determined in linseed was $\mathrm{K}>\mathrm{Mg}>\mathrm{Ca}>\mathrm{Na}$.

Among the sample sites highest concentration of $\mathrm{K}$ was determined in sample site Shoa $\left(6,755 \pm 78 \mathrm{mg} \mathrm{kg}^{-1}\right.$ dry weight) followed by South Wello $\left(6,644 \pm 47 \mathrm{mg} \mathrm{kg}^{-1}\right.$ dry weight $)$ and least value at East Gojam $\left(6,494 \pm 68 \mathrm{mg} \mathrm{kg}^{-1}\right.$ dry weight). In this study the concentration of $\mathrm{K}$ by sample sites decreases in the order Shoa $>$ South Wello $>$ Tigray $>$ Bale $>$ East Gojam $(6,755$ $\pm 78 ; 6,644 \pm 47 ; 6,539 \pm 61 ; 6522 \pm 72$ and $6,494 \pm 68 \mathrm{mg} \mathrm{kg}^{-1}$ dry weight, respectively). The one with highest concentration of Na was in the sample site South Wello $\left(614 \pm 23 \mathrm{mg} \mathrm{kg}^{-1} \mathrm{dry}\right.$ weight) followed by Tigray $\left(525 \pm 28 \mathrm{mg} \mathrm{kg}^{-1}\right.$ dry weight) and least amount of $\mathrm{Na}$ was in sample site Bale $\left(242 \pm 21 \mathrm{mg} \mathrm{kg}^{-1}\right.$ dry weight). Concentration decrement by sample sites can be arranged according to the order South Wello $>$ Tigray $>$ East Gojam $>$ Shoa $>$ Bale $(614 \pm 23$, $525 \pm 28,503 \pm 25,314 \pm$ and $242 \pm 21 \mathrm{mg} \mathrm{kg}^{-1}$ dry weight, respectively). The variation for $\mathrm{Na}$ level in linseed by sample site is somewhat wide and this may be attributed to the sample site distance from sea or lakes. As such the nearer the cultivation land to the lake, sea or ocean; the more amount of $\mathrm{Na}$ in that soil and the more amount can be absorbed by the plants [26, 27]. Similarly highest amount of $\mathrm{Mg}$ and $\mathrm{Ca}\left(3,118 \pm 25\right.$ and $744 \pm 8 \mathrm{mg} \mathrm{kg}^{-1}$ dry weight, respectively) and lowest amount $\left(2,679 \pm 23\right.$ and $540 \pm 9 \mathrm{mg} \mathrm{kg}^{-1}$ dry weight, respectively) were determined in sample sites South Wello and Tigray, respectively. The decreasing order for $\mathrm{Mg}$ and $\mathrm{Ca}$ by sample sites are South Wello $>$ East Gojam $>$ Shoa $>$ Bale $>$ Tigray and South Wello $>$ Bale $>$ Shoa $>$ East Gojam $>$ Tigray, respectively. The levels of $\mathrm{K}, \mathrm{Mg}$ and $\mathrm{Ca}$ in linseed did not show much variation by sample sites.

The higher levels of $\mathrm{K}$ and $\mathrm{Mg}$ in linseed is probably due to the fact that nutrient elements such as $\mathrm{N}, \mathrm{P}, \mathrm{K}, \mathrm{S}$, and $\mathrm{Mg}$ are highly mobile in the plant tissue and trans-located from old plant tissue to new plant tissue. The other probable reason for higher concentration of $\mathrm{K}$ and $\mathrm{Mg}$ is if the soil which have been used for cultivating the plant, are highly fertilized with manure and organic residues, they were high in available $\mathrm{K}$ and $\mathrm{Mg}$. Hence, the plant has high amount of these metals.

\section{Concentration of micro-essential (trace) metals in linseed}

As shown in Table $3 \mathrm{Fe}\left(198-242 \mathrm{mg} \mathrm{kg}^{-1}\right.$ dry weight) was the most accumulated trace metal followed by $\mathrm{Cu}\left(25-45 \mathrm{mg} \mathrm{kg}^{-1}\right.$ dry weight), Co (23-42 $\mathrm{mg} \mathrm{kg}^{-1}$ dry weight) and $\mathrm{Zn} \mathrm{(29-40} \mathrm{mg}$ $\mathrm{kg}^{-1}$ dry weight) in linseed sample. However, the concentration values of these trace metals indicates that the concentration ranges of trace metals overlap each other among the sample sites except $\mathrm{Fe}$ in which its value is higher in all sample sites and $\mathrm{Ni}\left(12-16 \mathrm{mg} \mathrm{kg}^{-1}\right.$ dry weight) in which lowest concentration values was determined. As such highest concentration of $\mathrm{Fe}$ was determined in sample site Shoa (242 $\pm 9 \mathrm{mg} \mathrm{kg}^{-1}$ dry weight) followed by East Gojam ( $232 \pm 0.8$ $\mathrm{mg} \mathrm{kg}^{-1}$ dry weight) and lowest in the sample site Bale $\left(198 \pm 2 \mathrm{mg} \mathrm{kg}^{-1}\right.$ dry weight $)$. The result for $\mathrm{Fe}$ in linseed indicates that the variation by sample site is very narrow. In general the concentration profile of Fe decreased by sample site was arranged in the order Shoa $(242 \pm 9 \mathrm{mg}$ 
$\mathrm{kg}^{-1}$ dry weight $)>$ East Gojam $\left(232 \pm 0.8 \mathrm{mg} \mathrm{kg}^{-1}\right.$ dry weight $)>$ Tigray $\left(216 \pm 7 \mathrm{mg} \mathrm{kg}^{-1}\right.$ dry weight $)>$ South Wello $\left(201 \pm 0.7 \mathrm{mg} \mathrm{kg}^{-1}\right)>$ Bale $\left(198 \pm 2 \mathrm{mg} \mathrm{kg}^{-1}\right)$.

The pattern of concentration of trace metals in linseed collected from sample site Bale was decreased as $\mathrm{Fe}>>\mathrm{Cu}>\mathrm{Zn}>\mathrm{Co}>\mathrm{Mn}>\mathrm{Cr}>$ Ni. Similarly the concentration profile according to this work was decreased in the order for sample site East Gojam ( $\mathrm{Fe}>>\mathrm{Co}>\mathrm{Zn}>\mathrm{Mn}>\mathrm{Cu}$ $>\mathrm{Ni}>\mathrm{Cr}$ ), Shoa $(\mathrm{Fe}>>\mathrm{Cu}>\mathrm{Cr} \approx \mathrm{Co} \approx \mathrm{Zn}>\mathrm{Mn}>\mathrm{Ni}$ ), South Wello $(\mathrm{Fe}>>\mathrm{Cu}>\mathrm{Co}>\mathrm{Zn}>$ $\mathrm{Cr}>\mathrm{Mn}>\mathrm{Ni})$ and Tigray $(\mathrm{Fe}>>\mathrm{Cu} \approx \mathrm{Zn}>\mathrm{Cr}>\mathrm{Co}>\mathrm{Mn}>\mathrm{Ni})$.

Consideration of individual metal by sample site indicates that the trend for $\mathrm{Cr}$ decreased by the order Tigray $\approx$ Shoa $>$ South Wello $>$ Bale $>$ East Gojam. For Mn the trend was almost opposite to that of $\mathrm{Cr}$ as East Gojam $>$ Bale $>$ Shoa $\approx$ South Wello $>$ Tigray. The trend for other trace metals was briefly arranged as for Co (East Gojam $>$ South Wello $>$ Shoa $>$ Bale $>$ Tigray); for Ni (South Wello $\approx$ Shoa $\approx$ East Gojam $\approx$ Bale $>$ Tigray); for Cu (South Wello $>$ Tigray $>$ Shoa $>$ Bale $>$ East Gojam) and for Zn (Tigray $>$ East Gojam $\approx$ South Wello $\approx$ Bale $>$ Shoa) based on this study of metals analysis by FAAS. The result for levels of trace metals in linseed indicates that the variation by sample site is very narrow.

The concentration values shown in Table 3 also show that the variations in concentrations of trace metals is not as much significant and comparable to each other. For example the concentration of $\mathrm{Ni}$ varies with in small range $\left(12-16 \mathrm{mg} \mathrm{kg}^{-1}\right.$ dry weight) and implies that the composition of $\mathrm{Ni}$ was invariant in comparison to other metals.

Results in this work for metal levels also indicate that the higher the concentration of the metal, the higher the variation in metal content by sample sites. Thus, the variation for Fe by sample sites is higher because Fe content in the sample was highest among the micro-essential metals and the variation for Ni by sample sites was smaller due to its lower content.

\section{Concentration of non-essential (toxic) metals in linseed}

Dietary exposure to $\mathrm{Cd}$ is estimated to be about $1.2 \times 10^{-4}$ to $4.9 \times 10^{-4} \mathrm{mg} \mathrm{kg}^{-1}$ of body weight daily. Intake of dietary Cd should not exceed $0.007 \mathrm{mg} \mathrm{kg}^{-1}$ of body weight, per week, according to the World Health Organization. For a healthy male of about $80 \mathrm{~kg}$ of body weight, that is only $0.56 \mathrm{mg}$ per week, a very small amount indeed. Cd is retained in the kidneys and liver (50 to 70 percent of accumulated $\mathrm{Cd}$ is deposited in these organs); excessive exposure can lead to kidney disease and serious liver damage. Possible effects of intense $\mathrm{Cd}$ exposure include emphysema, bone disorders such as osteoporosis and osteomalacia, cancer, and a shortened life span. However, the levels of $\mathrm{Cd}$ in this work was below method detection limits $\left(<0.001 \mathrm{mg} \mathrm{g}^{-1}\right)$ and using linseed for human nutrition may not affect human health due to the accumulation of $\mathrm{Cd}$ from linseed.

$\mathrm{Pb}$ is a major chemical pollutant of the environment, and is highly toxic to man. $\mathrm{Pb}$ can cause brain and kidney damage, decrease in hemoglobin production and male fertility. It enters human body by inhalation and ingestion, absorbed and carried by the blood; it is accumulated in liver, kidney, and bone up to about the fifth decade of life. $\mathrm{Pb}$ causes brain damage particularly to the young. There is evidence that $\mathrm{Pb}$ pollution can induce aggressive behavior in animals which can also occur in humans.

The values determined for $\mathrm{Pb}$ level in this work are presented in Table 3. As we can see from the table highest amount of $\mathrm{Pb}$ was determined from sample site Bale $\left(32 \pm 2.5 \mathrm{mg} \mathrm{kg}^{-1}\right.$ dry weight) followed by South Wello ( $28 \pm 1 \mathrm{mg} \mathrm{kg}^{-1}$ dry weight) and least concentration in sample site East Gojam (12 $\pm 1 \mathrm{mg} \mathrm{kg}^{-1}$ dry weight). Comparison of the $\mathrm{Pb}$ concentration by sample site decreased in the order Bale $>$ South Wello $>$ Tigray $>$ Shoa $>$ East Gojam. The variation for $\mathrm{Pb}$ content in linseed by sample site may be attributed to exposure to contamination during storage and transportation by cultivators. 


\section{Comparison of metal levels of the present study with literature values}

Comparison of analytical data with reference material is a common practice in analytical chemistry to validate the results. However, there is no standard reference material to do so and the determined results should be compared with the investigations made in other countries by other investigators. Earlier studies on linseed were made in different countries, in Ethiopia in particular, focused on the essential oil composition and biological aspects. Studies on the level of major, trace and toxic metal composition of the plant in Ethiopia was not carried out.

The comparative values of the results for macro-essential metals in this study with that was reported in the literatures were shown in Table 4. As the results in the table revealed, the levels of macro-essential metals determined in this work are in good agreement with other researchers' work that have been carried out in different countries and regions. For example the results in this study for these metals levels are almost similar with that reported by Kiralan et al. [12] from European Union, Hussain et al. [13] from Pakistan, Donatella et al. [14] from Italy and Iftikhar et al. [15] from south Asian regions. But the results in this study are higher than that reported by Khan et al. [28] from Pakistan for all macro-essential metals.

As shown in Table 4, the concentration of $\mathrm{K}\left(6,494-6,755 \mathrm{mg} \mathrm{kg}^{-1}\right.$ dry weight) determined in this study is in good agreement with other researchers like Kiralan et al. [12] $\left(8,770 \mathrm{mg} \mathrm{kg}^{-1}\right.$ dry weight) and Donatella et al. [14] $\left(8,820 \mathrm{mg} \mathrm{kg}^{-1}\right.$ dry weight). However, the result in this study for $\mathrm{K}$ level is to some extent higher than that reported by Iftikhar et al. [15] $\left(2,736 \mathrm{mg} \mathrm{kg}^{-1}\right.$ dry weight) in South Asian regions and much lower than that determined by Hussain et al. [13] $\left(13,690 \mathrm{mg} \mathrm{kg}^{-1}\right.$ dry weight). The results in this work also shows that $\mathrm{K}$ is the one with highest concentration among macro-essential metals as well as trace and heavy metals which is in agreement with that reported by all researchers in their work except that reported by Iftikhar et al. [15] $\left(2,736 \mathrm{mg} \mathrm{kg}^{-1}\right.$ dry weight) in which it is the second one next to Na. In general, the results in this work for $\mathrm{K}$ levels are within the range of values determined in the literatures.

Similarly the levels of $\mathrm{Na}$ determined in this work (242-614 $\mathrm{mg} \mathrm{kg}^{-1}$ dry weight) is somewhat in good agreement with that reported by Kiralan et al. [12] (689 $\mathrm{mg} \mathrm{kg}^{-1}$ dry weight) and Hussain et al. [13] (582 mg kg-1 dry weight). But the result in this study is much lower than that reported by Iftikhar et al. [15] $\left(5,005 \mathrm{mg} \mathrm{kg}^{-1}\right.$ dry weight). The $\mathrm{Mg}$ content of linseed determined in this study $\left(2,679-3,118 \mathrm{mg} \mathrm{kg}^{-1}\right.$ dry weight) is higher than that reported by Donatella et al. [14] (1,067 $\mathrm{mg} \mathrm{kg}^{-1}$ dry weight) and Iftikhar et al. [15] (126 mg kg-1 dry weight), almost comparable to that reported by Kiralan et al. [12] $\left(3,480 \mathrm{mg} \mathrm{kg}^{-1}\right.$ dry weight $)$ and much lower than that reported by Hussain et al. [13] (7,130 mg kg-1 dry weight). The level of Ca of this study (540-744 mg kg-1 dry weight) is comparable to that reported by Iftikhar et al. [14] (658 $\mathrm{mg} \mathrm{kg}^{-1}$ dry weight), but much lower than those determined by Kiralan et al. [12] $(1,858$ $\mathrm{mg} \mathrm{kg}{ }^{-1}$ dry weight), Hussain et al. [13] $\left(3,980 \mathrm{mg} \mathrm{kg}^{-1}\right.$ dry weight) and Donatella et al. [14] (1,930 $\mathrm{mg} \mathrm{kg}^{-1}$ dry weight).

Table 4. Comparison of macro-essential metals concentration, ( $\mathrm{mg} \mathrm{kg}^{-1}$, dry weight basis) in linseed samples with reported values.

\begin{tabular}{|c|c|c|c|c|c|}
\hline \multicolumn{4}{|c|}{ Concentration of metal $\left(\mathrm{mg} \mathrm{kg}^{-1}\right)$} & \multirow[t]{2}{*}{ Country } & \multirow[t]{2}{*}{ Reference } \\
\hline $\mathrm{K}$ & $\mathrm{Na}$ & $\mathrm{Mg}$ & $\mathrm{Ca}$ & & \\
\hline 8,770 & 689 & 3,480 & 1,858 & Europe & [12] \\
\hline 13,690 & 582 & 7,130 & 3,980 & Pakistan & [13] \\
\hline 8,820 & NR & 1,067 & 1,930 & Italy & [14] \\
\hline 2,736 & 5,005 & 126 & 658 & South Asia & [15] \\
\hline $6,494-6,755$ & $242-614$ & $2,679-3,118$ & $540-744$ & Ethiopia & This study \\
\hline
\end{tabular}

$\mathrm{NR}=$ not reported.

The levels of micro-essential metals in this study is almost similar with those reported in literatures except $\mathrm{Cr}$ and $\mathrm{Fe}$ in which the values determined here are to some extent higher than 
those values reported in the literature. The comparative results determined in this study with literature values are shown in Table 5 .

The level of $\mathrm{Cr}$ according to this work is within the range (13-30 $\mathrm{mg} \mathrm{kg}^{-1}$ dry weight) which is higher than that reported by Iftikhar et al. [15] $\left(<2 \mathrm{mg} \mathrm{kg}^{-1}\right.$ dry weight). The higher value for $\mathrm{Cr}$ level may not be concluded unless enough data from literatures are accessed. For $\mathrm{Mn}$ the concentrations determined (17-28 mg kg-1 dry weight) are almost similar (within the same range) with those reported from other countries. Fe in this study (198-242 $\mathrm{mg} \mathrm{kg}^{-1}$ dry weight) as well as those reported by others in the literatures is the one with higher concentration among trace metals however the values determined here are higher than others' determinations in the literature. It is also the one with highest concentration among all metals determined and reported by Khan et al. [28] (51 mg kg-1 dry weight) but not the case in this work. As researches in the recent years in Ethiopia indicated that the higher level of $\mathrm{Fe}$ in this study in comparison with other literature values may be attributed to the fact that the soil in Ethiopia is rich with $\mathrm{Fe}$ content. The concentration of $\mathrm{Co}$ and $\mathrm{Ni}$ determined in this work $\left(23-42 \mathrm{mg} \mathrm{kg}^{-1}\right.$ and $12-16 \mathrm{mg}$ $\mathrm{kg}^{-1}$ dry weight, respectively) is within the ranges reported by Donatella et al. [14] $\left(<1 \mathrm{mg} \mathrm{kg}^{-1}\right.$ and $0.8 \mathrm{mg} \mathrm{kg}^{-1}$ dry weight, respectively) to Iftikhar et al. [15] (76 $\mathrm{mg} \mathrm{kg}^{-1}$ and $19 \mathrm{mg} \mathrm{kg}^{-1}$ dry weight, respectively). The mean concentrations of $\mathrm{Cu}$ in present study $\left(25-45 \mathrm{mg} \mathrm{kg}^{-1}\right.$ dry weight) is in good agreement with those reported by Hussain et al. [13] (35 $\mathrm{mg} \mathrm{kg}^{-1}$ dry weight) and Iftikhar et al. [15] (25 mg kg${ }^{-1}$ dry weight), but a little bit higher than the values determined by Kiralan et al. [12] (12 mg kg dry weight), Khan et al. [28] (4.7 $\mathrm{mg} \mathrm{kg}^{-1}$ dry weight) and Donatella et al. [14] (15 mg kg dry weight). Zn concentration in this work (29-40 mg kg-1 dry weight) is also similar with other researchers like Kiralan et al. [12] (34 $\mathrm{mg} \mathrm{kg}^{-1}$ dry weight), Donatella et al. [14] (42 mg kg-1 dry weight) and Özkutlu et al. [16] (28 $\mathrm{mg} \mathrm{kg}^{-1}$ dry weight); somewhat lower from the value reported by Hussain et al. [13] (79 $\mathrm{mg} \mathrm{kg}^{-1}$ dry weight) and higher from the amount determined by Khan et al. [28] (14 $\mathrm{mg} \mathrm{kg}^{-1}$ dry weight).

The determination for levels of toxic metals was also carried out in this study and $\mathrm{Cd}$ was the one below method detection limit $\left(<0.001 \mathrm{mg} \mathrm{g}^{-1}\right)$. However, value as high as $0.13 \mathrm{mg} \mathrm{g}^{-1}$ dry weight is reported in literature from Turkey by Özkutlu et al. [16]. This implies the amount of $\mathrm{Cd}$ present in linseed is very small and using linseed for different feeding purposes may not affect human health, because of Cd over dosage is less. The level of $\mathrm{Pb}$ in this work (12-32 mg $\mathrm{kg}^{-1}$ dry weight) revealed that, it is higher than those reported by other researchers (Donatella et al. [14] and Iftikhar et al. [15] as presented in Table 5. Using linseed for feeding continuously may lead to toxic effects like brain and kidney damage, decrease in hemoglobin production and male fertility based on the values determined in this work. However, further investigation concerning $\mathrm{Pb}$ in linseed with other alternative methods and large sample size should be recommended to come up with a firm conclusion.

Table 5. Comparison of micro-essential and heavy metals concentration, ( $\mathrm{mg} \mathrm{kg}^{-1}$, dry weight basis) in linseed samples with reported values.

\begin{tabular}{|c|c|c|c|c|c|c|c|c|c|c|}
\hline \multicolumn{9}{|c|}{ Concentration of metal $\left(\mathrm{mg} \mathrm{kg}^{-1}\right)$} & \multirow[t]{2}{*}{ Country } & \multirow[t]{2}{*}{ Reference } \\
\hline $\mathrm{Cr}$ & $\mathrm{Mn}$ & $\mathrm{Fe}$ & Co & $\mathrm{Ni}$ & $\mathrm{Cu}$ & $\mathrm{Zn}$ & $\mathrm{Cd}$ & $\mathrm{Pb}$ & & \\
\hline NR & 30 & 76 & NR & NR & 12 & 34 & NR & NR & Europe & [12] \\
\hline NR & 47 & NR & NR & NR & 35 & 79 & NR & NR & Pakistan & [13] \\
\hline NR & 8.3 & 51 & NR & NR & 4.7 & 14 & NR & NR & Pakistan & [28] \\
\hline NR & 16 & 72 & $<1$ & 0.8 & 15 & 42 & NR & $<0.1$ & Italy & [14] \\
\hline$<2$ & 7.7 & NR & 76 & 19 & 25 & $\mathrm{NR}$ & NR & 1.7 & South Asia & [15] \\
\hline NR & $\mathrm{NR}$ & NR & NR & NR & NR & 28 & 0.13 & $\mathrm{NR}$ & Turkey & [16] \\
\hline $13-30$ & $17-28$ & $198-242$ & $23-42$ & $12-16$ & $25-45$ & $29-40$ & ND & $12-32$ & Ethiopia & This study \\
\hline
\end{tabular}

$\mathrm{NR}=$ not reported. $\mathrm{ND}=$ not detected.

In general, the concentrations of metals observed are more or less comparable with the reported literature values. However, relatively higher concentrations of $\mathrm{Cr}$ and $\mathrm{Fe}$ from essential

Bull. Chem. Soc. Ethiop. 2014, 28(3) 
metals and $\mathrm{Pb}$ from non-essential metals are observed in this study in comparison to the reported values.

Table 6. Analysis of variance (ANOVA) between and within linseed samples at $95 \%$ confidence level.

\begin{tabular}{|c|c|c|c|c|c|c|}
\hline Metal & Comparison & $\mathrm{SD}\left(\mathrm{mg} \mathrm{kg}^{-1}\right)$ & Df & $\mathrm{F}_{\mathrm{cal}}$ & $\mathrm{F}_{\text {crit }}$ & Remark \\
\hline \multirow[t]{2}{*}{$\mathrm{K}$} & $\begin{array}{l}\text { Between } \\
\text { samples }\end{array}$ & 108 & 4 & \multirow[t]{2}{*}{2.60} & \multirow[t]{2}{*}{2.61} & \multirow{2}{*}{$\begin{array}{l}\text { No significant } \\
\text { difference between } \\
\text { sample means }\end{array}$} \\
\hline & $\begin{array}{c}\text { Within } \\
\text { samples }\end{array}$ & 67.0 & 40 & & & \\
\hline \multirow[t]{2}{*}{$\mathrm{Na}$} & $\begin{array}{l}\text { Between } \\
\text { samples }\end{array}$ & 155 & 4 & \multirow[t]{2}{*}{43.1} & \multirow[t]{2}{*}{2.61} & \multirow[t]{2}{*}{$\begin{array}{l}\text { Significant difference } \\
\text { between sample means }\end{array}$} \\
\hline & $\begin{array}{c}\text { Within } \\
\text { samples }\end{array}$ & 23.6 & 40 & & & \\
\hline \multirow[t]{2}{*}{$\mathrm{Mg}$} & $\begin{array}{l}\text { Between } \\
\text { samples }\end{array}$ & 194 & 4 & \multirow[t]{2}{*}{58.3} & \multirow[t]{2}{*}{2.61} & \multirow[t]{2}{*}{$\begin{array}{l}\text { Significant difference } \\
\text { between sample means }\end{array}$} \\
\hline & $\begin{array}{c}\text { Within } \\
\text { samples }\end{array}$ & 25.4 & 40 & & & \\
\hline \multirow[t]{2}{*}{$\mathrm{Ca}$} & $\begin{array}{l}\text { Between } \\
\text { samples }\end{array}$ & 72.8 & 4 & \multirow[t]{2}{*}{35.6} & \multirow[t]{2}{*}{2.61} & \multirow[t]{2}{*}{$\begin{array}{l}\text { Significant difference } \\
\text { between sample means }\end{array}$} \\
\hline & $\begin{array}{l}\text { Within } \\
\text { samples }\end{array}$ & 12.2 & 40 & & & \\
\hline \multirow[t]{2}{*}{$\mathrm{Cr}$} & $\begin{array}{l}\text { Between } \\
\text { samples }\end{array}$ & 9.10 & 4 & \multirow[t]{2}{*}{93.7} & \multirow[t]{2}{*}{2.61} & \multirow[t]{2}{*}{$\begin{array}{l}\text { Significant difference } \\
\text { between sample means }\end{array}$} \\
\hline & $\begin{array}{c}\text { Within } \\
\text { samples }\end{array}$ & 0.94 & 40 & & & \\
\hline \multirow[t]{2}{*}{$\mathrm{Mn}$} & $\begin{array}{l}\text { Between } \\
\text { samples }\end{array}$ & 3.91 & 4 & \multirow[t]{2}{*}{22.7} & \multirow[t]{2}{*}{2.61} & \multirow[t]{2}{*}{$\begin{array}{l}\text { Significant difference } \\
\text { between sample means }\end{array}$} \\
\hline & $\begin{array}{c}\text { Within } \\
\text { samples }\end{array}$ & 0.82 & 40 & & & \\
\hline \multirow[t]{2}{*}{$\mathrm{Fe}$} & $\begin{array}{l}\text { Between } \\
\text { samples }\end{array}$ & 19.1 & 4 & \multirow[t]{2}{*}{24.0} & \multirow[t]{2}{*}{2.61} & \multirow[t]{2}{*}{$\begin{array}{l}\text { Significant difference } \\
\text { between sample means }\end{array}$} \\
\hline & $\begin{array}{l}\text { Within } \\
\text { samples }\end{array}$ & 3.90 & 40 & & & \\
\hline \multirow[t]{2}{*}{$\mathrm{Co}$} & $\begin{array}{l}\text { Between } \\
\text { samples }\end{array}$ & 7.52 & 4 & \multirow[t]{2}{*}{25.1} & \multirow[t]{2}{*}{2.61} & \multirow[t]{2}{*}{$\begin{array}{l}\text { Significant difference } \\
\text { between sample means }\end{array}$} \\
\hline & $\begin{array}{c}\text { Within } \\
\text { samples }\end{array}$ & 1.50 & 40 & & & \\
\hline \multirow[t]{2}{*}{$\mathrm{Ni}$} & $\begin{array}{l}\text { Between } \\
\text { samples }\end{array}$ & 1.52 & 4 & 1.84 & 2.61 & $\begin{array}{l}\text { No significant } \\
\text { difference between }\end{array}$ \\
\hline & $\begin{array}{c}\text { Within } \\
\text { samples }\end{array}$ & 1.12 & 40 & & & sample means \\
\hline $\mathrm{Cu}$ & $\begin{array}{l}\text { Between } \\
\text { samples }\end{array}$ & 7.54 & 4 & 20.1 & 2.61 & $\begin{array}{l}\text { Significant difference } \\
\text { between sample means }\end{array}$ \\
\hline & $\begin{array}{l}\text { Within } \\
\text { samples }\end{array}$ & 1.68 & 40 & & & \\
\hline $\mathrm{Zn}$ & $\begin{array}{l}\text { Between } \\
\text { samples }\end{array}$ & 3.96 & 4 & 50.0 & 2.61 & $\begin{array}{l}\text { Significant difference } \\
\text { between sample means }\end{array}$ \\
\hline & $\begin{array}{c}\text { Within } \\
\text { samples }\end{array}$ & 0.56 & 40 & & & \\
\hline $\mathrm{Pb}$ & $\begin{array}{l}\text { Between } \\
\text { samples }\end{array}$ & 8.10 & 4 & 25.6 & 2.61 & $\begin{array}{l}\text { Significant difference } \\
\text { between sample means }\end{array}$ \\
\hline & $\begin{array}{l}\text { Within } \\
\text { samples }\end{array}$ & 1.60 & 40 & & & \\
\hline
\end{tabular}

$\mathrm{SD}=$ standard deviation, $\mathrm{Df}=$ degree of freedom, $\mathrm{F}_{\text {cal }}=\mathrm{F}$ calculated, $\mathrm{F}_{\text {crit }}=\mathrm{F}$ critical.

Bull. Chem. Soc. Ethiop. 2014, 28(3) 


\section{Pearson correlation}

In this study, to correlate the effect of one metal concentration on the concentration of the other metal, the Pearson correlation matrices using correlation coefficient ( $r$ ) for the samples were used and presented in Table 7. The values of Pearson correlation coefficient revealed that there is weak and/or moderate positive or negative correlation of metals with each other except for some metals. The weak negative or positive correlation indicating that the presence or absence of one metal affect in lesser extent to the other. Some exception observable from the table is that, there is high positive correlation for $\mathrm{K}$ with $\mathrm{Cr}, \mathrm{Mg}$ with $\mathrm{Co}$ and $\mathrm{Ni}, \mathrm{Ca}$ with $\mathrm{Ni}, \mathrm{Cr}$ with $\mathrm{Cu}$, Mn with $\mathrm{Co}$ and $\mathrm{Co}$ with $\mathrm{Ni}$; which may arise from common anthropogenic or natural sources as well as from similarity in chemical properties. The high negative correlation between $\mathrm{Fe}$ and $\mathrm{Pb}$ indicate that large absorption of $\mathrm{Fe}$ may affect the absorption of $\mathrm{Pb}$ in linseed plant.

Table 7. Pearson correlation matrices for metals in linseed sample $(n=5)$.

\begin{tabular}{|c|c|c|c|c|c|c|c|c|c|c|c|c|}
\hline & $\mathrm{K}$ & $\mathrm{Na}$ & $\mathrm{Mg}$ & $\mathrm{Ca}$ & $\mathrm{Cr}$ & $\mathrm{Mn}$ & $\mathrm{Fe}$ & $\mathrm{Co}$ & $\mathrm{Ni}$ & $\mathrm{Cu}$ & $\mathrm{Zn}$ & $\mathrm{Pb}$ \\
\hline $\mathrm{K}$ & 1 & & & & & & & & & & & \\
\hline $\mathrm{Na}$ & -0.12 & 1 & & & & & & & & & & \\
\hline $\mathrm{Mg}$ & 0.48 & 0.37 & 1 & & & & & & & & & \\
\hline $\mathrm{Ca}$ & 0.32 & 0.25 & 0.75 & 1 & & & & & & & & \\
\hline $\mathrm{Cr}$ & 0.70 & 0.23 & -0.01 & -0.07 & 1 & & & & & & & \\
\hline $\mathrm{Mn}$ & -0.23 & -0.10 & 0.56 & 0.35 & -0.81 & 1 & & & & & & \\
\hline $\mathrm{Fe}$ & 0.38 & -0.11 & 0.30 & -0.38 & 0.14 & 0.25 & 1 & & & & & \\
\hline $\mathrm{Co}$ & -0.09 & 0.38 & 0.82 & 0.59 & -0.53 & 0.86 & 0.18 & 1 & & & & \\
\hline $\mathrm{Ni}$ & 0.42 & 0.12 & 0.93 & 0.88 & -0.19 & 0.64 & 0.07 & 0.79 & 1 & & & \\
\hline $\mathrm{Cu}$ & 0.47 & 0.29 & -0.06 & 0.29 & 0.80 & -0.79 & -0.47 & -0.48 & -0.07 & 1 & & \\
\hline $\mathrm{Zn}$ & -0.68 & 0.57 & -0.53 & -0.46 & 0.03 & -0.41 & -0.32 & -0.25 & -0.68 & 0.12 & 1 & \\
\hline $\mathrm{Pb}$ & -0.06 & -0.19 & -0.35 & 0.36 & 0.07 & -0.40 & -0.91 & -0.41 & -0.07 & 0.61 & 0.04 & 1 \\
\hline
\end{tabular}

\section{CONCLUSSION}

In this study metal levels in linseed from five different regions in Ethiopia were analyzed for their contents of $\mathrm{K}, \mathrm{Na}, \mathrm{Mg}, \mathrm{Ca}, \mathrm{Cr}, \mathrm{Mn}, \mathrm{Fe}, \mathrm{Co}, \mathrm{Ni}, \mathrm{Cu}, \mathrm{Zn}, \mathrm{Cd}$ and $\mathrm{Pb}$ using flame atomic absorption spectrometer. The optimized wet digestion method for linseed analysis was evaluated through the recovery experiment and a good percentage recovery was obtained (100 \pm 10$)$ for all the metals identified. The levels of essential metals in linseed determined in this study varied in the order $\mathrm{K}\left(6494-6755 \mathrm{mg} \mathrm{kg}^{-1}\right)>\mathrm{Mg}\left(2679-3118 \mathrm{mg} \mathrm{kg}^{-1}\right)>\mathrm{Ca}\left(540-744 \mathrm{mg} \mathrm{kg}^{-1}\right)>\mathrm{Na}$ $\left(242-614 \mathrm{mg} \mathrm{kg}^{-1}\right)>\mathrm{Fe}\left(198-242 \mathrm{mg} \mathrm{kg}^{-1}\right)>\mathrm{Cu}\left(25-45 \mathrm{mg} \mathrm{kg}^{-1}\right)>\mathrm{Ni}\left(12-16 \mathrm{mg} \mathrm{kg}^{-1}\right)$ and approximately overlapping ranges for the other metals. The non-essential heavy metal, Cd, was found to be below the method detection limit. The results of this work indicated that linseed accumulates relatively higher amounts of $\mathrm{K}$ and $\mathrm{Pb}$ among the determined essential and nonessential metals, respectively. The contents of minerals in linseed in this study were within the daily recommended level and thus advisable as healthy food for treatment of different health complications.

Statistical analysis by using one way ANOVA indicated that there is significant difference in mean concentration of metals between sampling sites except $\mathrm{K}$ and $\mathrm{Ni}$. This may be attributed to differences in soil composition, use of different fertilizers, pesticides, and quality of irrigation water. For $\mathrm{K}$ and $\mathrm{Ni}$, the difference may only be attributed to random errors in the experimental procedures. The concentration of $\mathrm{Pb}$ determined in this work is somewhat higher from other experimental results using the same method. In general the metal contents in linseed in Ethiopia are comparable to that reported in the rest of the world. 


\section{ACKNOWLEDGEMENTS}

The authors express their gratitude to the Department of Chemistry, Addis Ababa University, Ethiopia, for providing the laboratory facilities. Desta Mekebo is thankful to Department of Chemistry, Mizan-Tepi University, Ethiopia, for sponsoring his study.

\section{REFERENCES}

1. Aruchalam, V. Indian J. Gen. Plant Breed. 1981, 41, 226.

2. Wakjira, A.; Tekilewolde, A. Agronomic performance of linseed regenerants at two locations in Ethiopia, in Proceedings of the $7^{\text {th }}$ Annual Conference of the Crop Science Society of Ethiopia (CSSE), 27-28 April 1995, Addis Ababa, Ethiopia, 9-21.

3. Wakjira, A. Linseed (Linum usitatissimum L.), in Vegetable Oils and Fats, Plant Resource of Tropical Africa (PROTA). Vandervossen, H.A.M.; Kamilo, G.S.M. (Eds.), No. 14, PROTA Foundation, Wageningen, Netherlands, 2007, 108-115.

4. Central Statistic Organization (CSO), Time Series Data on Area, Production and Yield of Principal Crops by Regions, Central Statistics Office, Addis Ababa, Ethiopia, 1984.

5. Alemayehu, G.; Alemayehu, N. Highland Oil Crops: A Three-decade Research Experience in Ethiopia, Research Report No 30, Institute of Agricultural Research, Addis Ababa, Ethiopia, 1997.

6. Central Statistic Authority (CSA), Crop Production Forecast Sample Survey, Report on area, production and yield of major crops for private holdings, Report number 439, Addis Ababa, Ethiopia, 2008.

7. Huang, S.; Milles, D. Gamma-linolenic Acid: Metabolism and Its Roles in Nutrition and Medicine, AOCS Press: Champaign, IL, USA; 1996.

8. Huang, S.; Ziboh, A. Gamma-linolenic Acid: Recent Advances in Biotechnology and Clinical Applications, AOCS Press: Champaign, IL, USA; 2001.

9. Simopoulos, A.P. Biomed. Pharmacother. 2002, 56, 365.

10. El-Beltagi, H.; Salama, Z.; El-Hariri, D. Gen. Appl. Plant Physiol. 2007, 33, 187.

11. Chauhan, M.P.; Singh, S.; Singh, A.K. J. Hum. Ecol. 2009, 28, 217.

12. Kiralan, M.; Gokpinar, F.; Ipek, A.; Bayrak, N.; Arslan, M.; Kok, S. Spanish J. Agric. Res. 2010, 8, 1068.

13. Hussain, S.; Faqir, M.A.; Masood, S.B.; Munir, A.S. Sarhad J. Agric. 2008, 24, 649.

14. Donatella, D.; Maria, A.M.; Carla, R. Microchem. J. 2010, 95, 174.

15. Iftikhar, A.; Muhammad, A.H.; Raziya, N.; Muhammad, S.J.; Muhammad, S.Z. J. Chem. Soc. Pak. 2008, 30, 400

16. Özkutlu, F.; Kara, S.M.; Şekeroğlu, N. ISHS Acta Hort. 2007, 756, 32.

17. Derbie, A.; Chandravanshi, B.S. Biol. Trace Elem. Res. 2011, 141, 317.

18. Debebe, A.; Chandravanshi, B.S.; Wondimu, T. SINET: Ethiop. J. Sci. 2012, 35, 71.

19. Kitata, R.B.; Chandravanshi, B.S. Bull. Chem. Soc. Ethiop., 2012, 26, 27.

20. Weldegebriel, Y.; Chandravanshi, B.S.; Wondimu, T. Ecotoxicol. Environ. Saf. 2012, 77, 57.

21. Gebre, A.; Chandravanshi, B.S. Bull. Chem. Soc. Ethiop., 2012, 26, 329.

22. Shegro, A.; Shargie, N.G.; van Biljon, A.; Labuschagne, M.T. J. Crop Sci. Biotech. 2012, $15,275$.

23. Aregahegn, A.; Chandravanshi, B.S.; Atlabachew, M. Acta Hort. (ISHS) 2013, 979, 117.

24. Aregahegn, A.; Chandravanshi, B.S.; Atlabachew, M. Afr. J. Food Agric. Nutr. Dev. 2013, 13,7870 .

25. Duman, E.; Özcan, M.M. Environ. Monit. Assess. 2014, 186, 239.

26. Robert, B.D. Botanical Gazette 1925, 79, 233.

27. Stephen, G.P. Physiology of Woody Plants, 3rd ed., Elsevier: London; 2008.

28. Khan, L.; Sharif, M.; Sarwar, M.; Sameea, L.; Ameen, M. Pak. Veterinary J. 2010, 30, 79.

29. Miller, J.N.; Miller, J.C. Statistics and Chemometrics for Analytical Chemistry, 4th ed., Pearson Education Limited: Harlow, England; 2000. 